\title{
Early Life History of the Sevenband Grouper, Epinephelus septemfasciatus from Korea
}

\author{
Jae-Min Park ${ }^{1}$, Jae-Kwon Cho ${ }^{1}$, Kyeong-Ho Han ${ }^{2}$, Na-ri Kim ${ }^{1}$, Hyung-Kyu Hwang ${ }^{3}$, \\ Kyong-Min Kim ${ }^{1}$, Jeong-In Myeong ${ }^{3}$, and ${ }^{\dagger}$ Maeng-Hyun Son ${ }^{1}$ \\ ${ }^{1}$ Southwest Sea Fisheries Research Institute, National Fisherise Research and Development Institute, \\ Aquaculture Industry Division, NFRDI, Yeosu 556-823, Republic of Korea \\ ${ }^{2}$ Department of Aqualife Science, Chonnam National University, Yeosu 550-749, Republic of Korea \\ ${ }^{3}$ Aquaculture Research Institute, NFRDI, Busan 619-902, Republic of Korea
}

\begin{abstract}
This study is conducted to monitor the morphological developmental features of the egg development, larvae and juvenile of Epinephelus septemfasciatus, the fertilized eggs were gotton using artificial insemination. Matured parents are collected from marine caged fish farms in Geomun-ri, Samsan-myeon, Yeosu-si, Jeollanamdo Korea in June 2012. The fertilized eggs were pelagic eggs containing one oil globule, and measured 0.81 0.89 $\mathrm{mm}(0.85 \pm 0.04 \mathrm{~mm}, \mathrm{n}=50)$ in diameter. In regard to rearing environment, the water temperature is $21.0 \sim 23.0^{\circ} \mathrm{C}$ and the salinity is $32.0 \sim 33.2 \%$. Hatching was observed from 48 hours after fertilization, the mouth and anus of prelarvae was not opened but had egg yolk at newly hatched. 4 days after hatching, the mouth and anus of postlarvae was opened and began to eat Rotifer and was measured $2.40 \sim 2.49 \mathrm{~mm}$ $(2.45 \pm 0.03 \mathrm{~mm} \mathrm{n}=10)$ in total length. 12 days after hatching, postlarvae was measured $3.77 \sim 4.67 \mathrm{~mm}(4.27 \pm 0.33 \mathrm{~mm})$ in total length, its the second pole tide of dorsal fin and the first pole tide of pelvic fin was extended longitudinally. 71 days after hatching, juvenile was measured 40.5 45.4 mm $(42.6 \pm 2.04 \mathrm{~mm})$ in total length. Seven bands were observed in body, and pole tides of dorsal and pelvic fins were shortened.
\end{abstract}

Key words : Egg development, Juvenile, Larvae, Sevenband grouper

\section{INTRODUCTION}

Investigations regarding early life history of fish deal with morphological and physiological characteristics of eggs as well as a vast amount of information including unique traits and developmental characteristics of species, appearing through the embryogenesis and its early growth thus, not only provide taxonomic, embryological, and ecological information but also can be utilized in various aspects such as conservation and protection of fishes resources, and farming via seed production (Song \& Choi, 2000).

Sevenband grouper, Epinephelus septemfasciatus is classified as Perciformes and Serranidae there are 62 genus and 450 species. 12 genus and 27 species, including $E$. septemfasciatus, E. akaara, and E. bruneus are found in Korea (Kim et al., 2005). E. septemfasciatus generally prey on small fishes and crustacean, and ihabit in 10 20 m

\footnotetext{
Manuscript received 2 January 2014, Received in revised form 23 January 2014, Accepted 3 February 2014

'Corresponding Author : Maeng-Hyun Son, Southwest Sea Fisheries Research Institute, National Fisherise Research and Development Institute, Aquaculture Industry Division, NFRDI, Yeosu 556-823, Republic of Korea. Tel : +82-61-690-8978, Fax : +82-61-685-9073, E-mail : gost016803@naver.com

This is an Open Access article distributed under the terms of the Creative Commons Attribution Non-Commercial License (http:// creativecommons.org/licenses/by-nc/3.0) which permits unrestricted non-commercial use, distribution, and reproduction in any medium, provided the original work is properly cited.
} 
water depth with thick seaweeds; as grow, move to 100 $200 \mathrm{~m}$ water depth around reef area.

Morphologically, their body and head are flat and like a long oval shape there are 7 dense dark brown horizontal stripes on the body while a white border line at the edge of a caudal fin (Jung, 1977; Kim et al., 2005). There are several studies have been done in Korea including investigations in regards to its phototaxis (Yang, 1987), mass mortality (Sohn et al., 1991), ovulation induction (Kim et al., 1997), nervous necrosis pathogenic virus (Sohn \& Chun, 1999), behavior control (Yang, 1999), sex reversal induction (Song et al., 2005), as well as VNN developmental pattern (Kim et al., 2012). Meanwhile, there are researches have been done in other countries about the growth and patterns of crossbred game fishing (Miyailara et al., 1989), egg development and morphologic development of larvae and juvenile (Kitajima et al., 1991), feeding selectivity of larvae depending upon sizes of rotifers (Tanaka et al., 2005), artificial insemination using frozen sperm (Miyaki et al., 2006) and anomalies of larvae and juvenile (Nagano et al., 2007).

Considerable interests have been placed on E. septemfasciatus as a high value added industrial species due to its recent spiked demands and limited resources. Owing to such circumstances, meaning high demand on E. septemfasciatus, some are being imported from foreign countries thus it is warranted to put more emphasis on investigations in regard to industrialization of E. septemfasciatus farming (Lee \& Go, 2003). There fore, in the present study, we investigated increased production yield of E. septemfasciatus farming, stable seed production, elucidation of their early life history, as well as morphological development of larvae and juvenile depending upon their progress of egg development and growth maturation there by providing basic biological data.

\section{MATERIALS AND METHODS}

Parent fishes used in the study were obtained from a cage aquaculture in July $2012(7 \times 7$ m; located in Geomunri Samsan-myeon, Yeosu-si, Jeollanamdo, Korea) fishes were aquacultured and fed with Trachurus japonicus as well as extrusion pellet for 8 years. Matured 5 fishes, both sex, with total length (TL) around $67.5 \mathrm{~cm}$ to $83.5 \mathrm{~cm}$ $(74.8 \pm 5.3 \mathrm{~cm})$ were chosen for the study.

Once confirmed fishes are matured, selected fishes, both sexes, were injected with human chorionic gonadotropin (HCG; 500 IU per kg body weight) and then eggs and sperms were collected through abdominal pressure. Obtained eggs and sperms were artificially fertilized using the wet method and washed twice with filtered seawater. Eggs that may exhibit high fertility rate were collected, packed using vinyl bags with oxygen, and transferred to the laboratory. The experimental conditions for egg development were maintained as follow: the temperature of water was between $21.5^{\circ} \mathrm{C}$ to $23.5^{\circ} \mathrm{C}$ and the concentration of salt was around in the range of $32.5 \%$ to $33.5 \%$. Half of water in fish tanks (filtered seawater) was changed daily. Fifty fertile eggs were randomly selected and subjected to the measurement of egg diameter as well as the oil droplet size using a profile projector (JP V-12B; Nikon, Tokyo, Japan) up to $0.01 \mathrm{~mm}$ while processes of egg development were observed and photos were taken using a stereoscopic microscope (NM-40; Nikon, Tokyo, Japan) equipped with a digital camera (Coolpix 995; Nikon, Tokyo, Japan).

Morphological developments of larvae and juvenile were observed from hatching through the juvenile stage. Once hatched, fishes were accommodated in a circular fish tank made of polypropylene $(100 \times 50 \times 80 \mathrm{~cm})$ the water temperature and the concentration of salt were maintained between $22.5^{\circ} \mathrm{C}$ and $24.5^{\circ} \mathrm{C}$ and $32.0 \%$ to $33.2 \%$, respectively throughout the breeding period. The water condition for the present experiment was maintained as pond culture system for early hatching period whilst half of water in fish tanks was daily replaced after 10 days of hatching. 


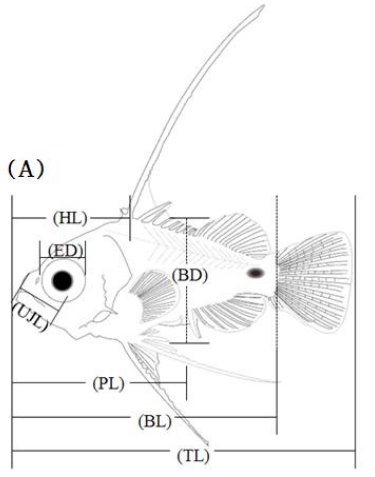

(B)

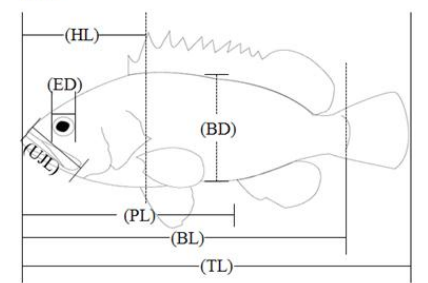

Fig. 1. Diagram showing measurements of Epinephelus septemfasciatus. (A) Larvae; (B) Juvenile; Total length (TL); Body length (BL); Preanal length (PL); Head length (HL); Eye diameter (ED); Upper jaw length (UPL); Body depth (BD).

Table 1. Composition of fecundity by total length of sevenband grouper, Epinephelus septemfasciatus

\begin{tabular}{ccc}
\hline $\begin{array}{c}\text { Total length } \\
(\mathrm{cm})\end{array}$ & $\begin{array}{c}\text { Total weight } \\
(\mathrm{kg})\end{array}$ & $\begin{array}{c}\text { Number of eggs } \\
\left(\times 10^{2}\right)\end{array}$ \\
\hline 68.0 & 7.27 & 199 \\
72.5 & 8.69 & 599 \\
74.5 & 8.84 & 624 \\
75.5 & 9.67 & 1,647 \\
\hline
\end{tabular}

During the breeding period, larvae and juvenile were fed with rotifer (Branchionus rotundiformis), brine shrimp (nauplius of Artemia sp.) as well as initial formula feed. In order to monitor morphological developments of fish larvae, average 10 fishes were taken per day right after hatching and then tricane methasulfonate (MS-222, Sandoz, Holzkirchen, Germany). Once anesthetized, 7 traits of fish (Fig. 1), body length (BL), total length (TL), eye diameter (ED), head length (HL), preanal length (PL), body depth (BD), and upper jaw length (UJL), were measured up to $0.01 \mathrm{~mm}$ utilizing a profile projector and stereoscopic microscope further, the morphological developmental stages were classified as described elsewhere (Rusell, 1976).

\section{RESULTS}

\section{Fecundity and size of spawn}

Throughout the present experiments, the fecundity of female parent of E. septemfasciatus was investigated and summarized in Table 1. The average TL of experimental fish was between $68.0 \sim 75.5 \mathrm{~cm}$ and the fecundity was found to be approximately 199,680 to $1,647,360$ (average $767,520)$ in general the longer TL, the more of fecundity was observed. The fertile egg size was around $0.80 \mathrm{~mm}$ to $0.89 \mathrm{~mm}(0.82 \pm 0.02 \mathrm{~mm})$ and a single oil droplet, about $0.17 \mathrm{~mm}$ to $0.19 \mathrm{~mm}(0.18 \pm 0.01 \mathrm{~mm})$ was found.

\section{Developmental processes of egg}

Cleavage of artificially inseminated egg was divided into two within 1 hour and then reached to the 2 cell stage (Fig. 2A) subsequently, it was reached to 4 cell stage (Fig. 2B), 8 cell stage (Fig. 2C), 16 cell stage (Fig. 2D), and 32 cell stage (Fig. 2E) after 2, 3, 4.5, and 5.5 hours, respectively. As the cleavage was getting smaller, the egg was in the morula stage after 8 hours (Fig. 2F). Fifteen hours later, the egg was in the blastula stage (Fig. $2 \mathrm{G}$ ) and blastoderm was covered by yolk and reached in the early gastrula stage (Fig. 2H). Blastoderm as well as yolk were enlarging after 26 hours of insemination (Fig. 2I) followed by the formation of optical vesicle and Kuffer's vesicle after 34 hours (Fig. 2J). About 8 to 9 of myotomes were formed during these developmental processes (Fig. 2K).

The Kuffer's vesicle was disappeared whilst the numbers of myotome were increased around 12 to 13 after 37 hours of hatching (Fig. 2L). Subsequently, after 43 hours of hatching, eye lenses were differentiated and then formed otic capsules at the same time, myotomes were about 17 to 18 (Fig. 2M). After 46 hours of hatching, the embryo began to move, formed the heart with heart rate around 62 to 72 per minute (Fig. 2N). Eventually, after 48 hours, the head break through the egg membrane it was becoming just before the hatching (Fig. 2O) and then initiated hatching right away (Fig. 2P). 

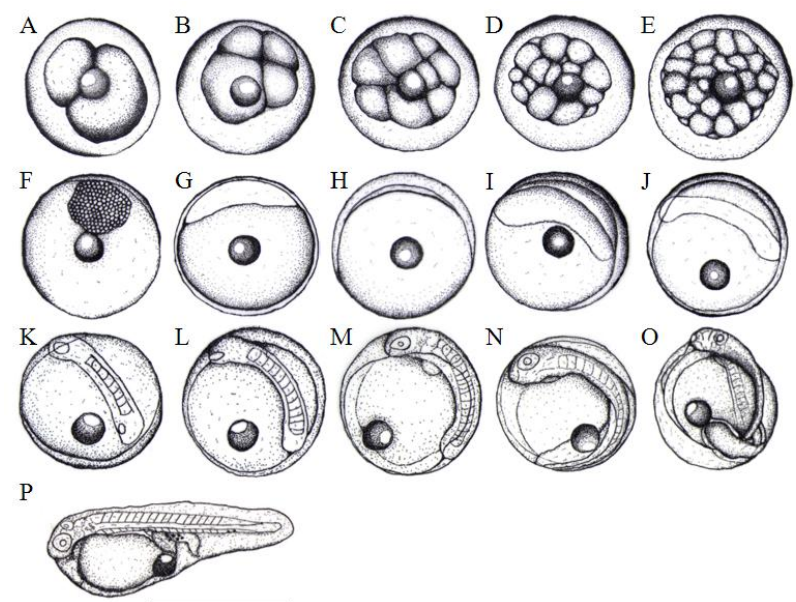

Fig. 2. Egg development stages of sevenband grouper, Epinephelus septemfasciatus. (A) 2 cell stage; (B) 4 cell stage; (C) 8 cell stage; (D) 16 cell stage; (E) 32 cell stage; (F) Morula stage; (G) Blastula stage; (H) Gastrula stage; (I)-(J) Formation of embryo; (K) Kuffer's vesicles appearance; (L) 12 13 mytomes stage; (M) Formation of eyes; (N) Heart beat; (O) Hatching; $(\mathrm{P})$ Hatched larvae. Scale bar $=1.0 \mathrm{~mm}$.

\section{Morphological development of larvae and juvenile}

\section{1) Prelarvae stage}

Just after hatched, the TL of prelarvae is between 1.28 $\mathrm{mm}$ to $1.95 \mathrm{~mm}(1.74 \pm 0.24 \mathrm{~mm}, \mathrm{n}=10)$ and the mouth and anus yet to be opened. There was one oil droplet and fins were like membrane shape and connect the dorsal center line of back head, tail, yolk and bottom of head. There were five and melanophores in the upper digestive tract, while only one or two of them, spot shaped, were shown in tail. The anus was located in approximately $62.1 \%$ behind of TL from very center (Fig. 3A). After 2 days of hatching, the TL of prelarvae was around 1.75 2.36 mm $(2.05 \pm 0.21$ $\mathrm{mm})$ and the oil droplet was noticeably shrunken the mouth and anus were not completely opened. There was no significant difference in fins on membranes whereas the caudal fin was begun to differentiate. The yolk was almost completely absorbed and melanophore beneath a tail was shown as a single big dark spot (Fig. 3B).
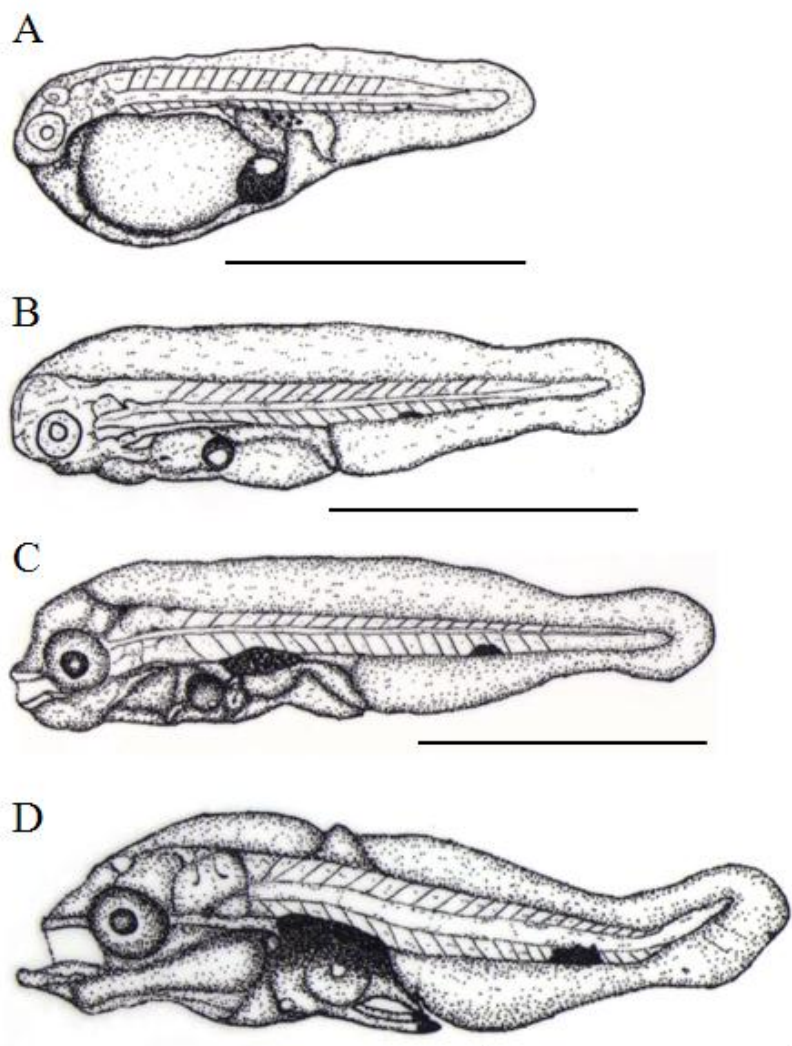

Fig. 3. Development of prelarvae and postlarvae sevenband grouper, Epinephelus septemfasciatus. (A) Newly hatched larvae; $1.74 \mathrm{~mm}$ in total length (TL); (B) $2.05 \mathrm{~mm}$ in TL prelarvae, 2 days after hatching; (C) $2.45 \mathrm{~mm}$ in TL prelarvae, 4 days after hatching; (D) $2.54 \mathrm{~mm}$ in TL postlarvae. Scale bars $=1.0 \mathrm{~mm}$.

\section{2) Postlarvae stage}

After 4 days of hatching, the TL of postlarvae was 2.40 $\mathrm{mm}$ to $2.49 \mathrm{~mm}(2.45 \pm 0.03 \mathrm{~mm})$ and it developed the lower jar with further differentiated the pectoral fin with opening the mouth and anus. Melanophores were precipitated on eyes and the upper intestinal tract further it was widely and horizontally distributed over bottom of tail (Fig. 3C). The TL of postlarvae was about $2.48 \sim 2.59 \mathrm{~mm}(2.54 \pm 0.05$ $\mathrm{mm}$ ) and the oil droplet was mostly absorbed. There were two bones in the ventral fin while a fish bone was formed in the dorsal fin. Melanophores were newly formed at both ends of the ventral fin and melanophores of tail were more precipitated on the very center of the caudal peduncle (Fig. 
3D). After 12 days of hatching, the TL of postlarvae was between $3.77 \mathrm{~mm}$ to $4.67 \mathrm{~mm}(4.27 \pm 0.33 \mathrm{~mm})$ and a terminal notochord of the tail was bended $45^{\circ} \mathrm{C}$, membrane like fins were differentiated and then, connected from back head, tail, and the anus. The bones were formed in the dorsal fin and the second bone was the longest there are also 2 bones developed lengthy in ventral fin.

Melanophores were appeared very dark at the end of both dorsal fin and ventral fin in addition, melanophores were widely shown throughout the abdominal cavity and bottom of tail (Fig. 4E). After 20 days of hatching, the TL of postlarvae was $4.79 \mathrm{~mm}$ to $5.99 \mathrm{~mm}(5.39 \pm 0.41 \mathrm{~mm})$ and membrane like fin was connected through the third bone of the dorsal fin to the tail and anus. Further the anal fin started to differentiate. The numbers of dorsal fin become three and melaophores were precipitated on the back of eyes, like small spots (Fig. 4F).

After 29 days of hatching, the TL of postlarvae was between $6.01 \mathrm{~mm}$ and $8.90 \mathrm{~mm}(7.58 \pm 0.93 \mathrm{~mm})$ and an anal fin as well as dorsal fin were beginning to differentiate and 10 to 11 melanophores were shown in abdominal cavity, like spots (Fig. 4G).

After 31 days of hatching, the TL of postlarvae was 9.72 $\mathrm{mm}$ to $14.7 \mathrm{~mm}(11.9 \pm 1.96 \mathrm{~mm})$ and membrane fin was completely separated. Melanophores were newly found on the top of head while melanophores in the bottom tail were located in the very center of caudal peduncle. Spot like melanophores on the abdominal cavity was enlarged and shown like a big dot (Fig. 4H).

After 38 days of hatching, the TL of postlarvae was 12.2 $\mathrm{mm}$ to $17.1 \mathrm{~mm}(14.4 \pm 1.85 \mathrm{~mm})$ and second bone of the dorsal fin as well as first bone of the ventral fin was further developed. Melanophores present in the very center of the caudal peduncle were widely precipitated like spots (Fig. 5I). After 44 days of hatching, the TL of postlarvae was around $15.6 \mathrm{~mm}$ to $18.9 \mathrm{~mm}(17.3 \pm 1.40 \mathrm{~mm})$ and by and large, melanophores were found in bottom of eyes, upper

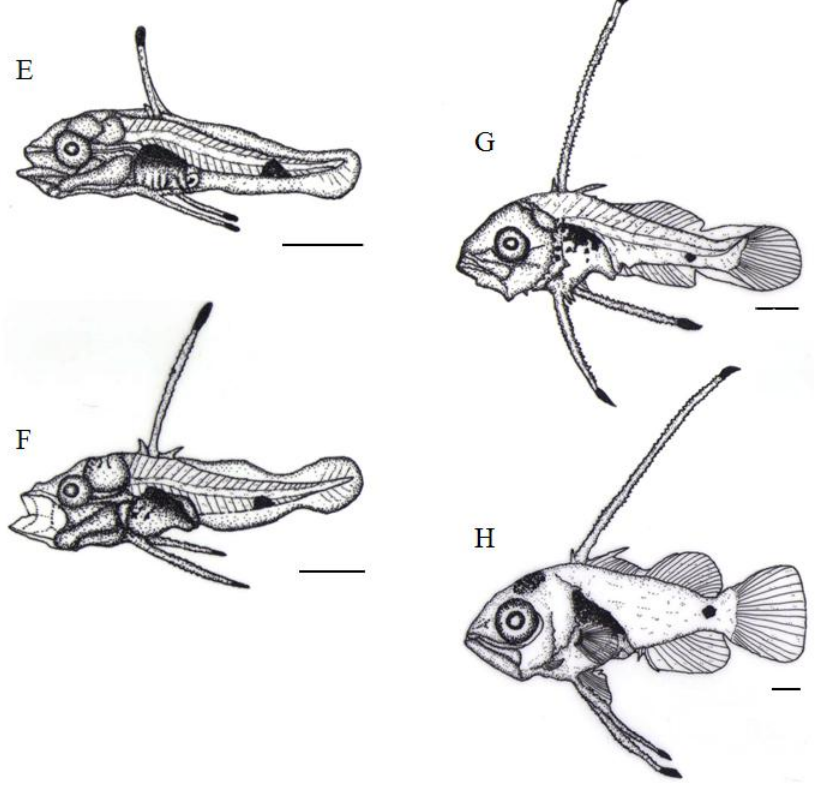

Fig. 4. Development of postlarvae sevenband grouper, Epinephelus septemfasciatus. (E) $4.27 \mathrm{~mm}$ in TL postlarvae, 12 days after hatching; (F) $5.39 \mathrm{~mm}$ in TL postlarvae, 20 days after hatching; (G) $7.58 \mathrm{~mm}$ in TL postlarvae, 29 days after hatching; (H) 11.9 $\mathrm{mm}$ in TL postlarvae, 31 days after hatching. Scale bars $=1.0 \mathrm{~mm}$.

part of operculum, and head through caudal peduncle, further there were more of melanophores, precipitated like dots on back side, an anal fin bone, as well as its bottom part (Fig. 5J). After 52 days of hatching, the TL of postlarvae was between $18.3 \mathrm{~mm}$ to $26.2 \mathrm{~mm}(21.3 \pm 2.17 \mathrm{~mm})$ and second bone of the dorsal fin and first bone of the ventral fin gradually got shorter and precipitated melanophores found in the whole body got darker in color, eventually 7 horizontal stripes were shown (Fig. 5K).

\section{3) Juvenile stage}

After 61 days of hatching, the TL of juvenile is around $30.7 \mathrm{~mm}$ to $34.5 \mathrm{~mm}(32.9 \pm 1.38 \mathrm{~mm})$ and second bone of the dorsal fin and first bone of ventral fin were almost got shorten. Melanophores found in the head and an operculum got darker.

They were also widely precipitated on back side, abdomen, 

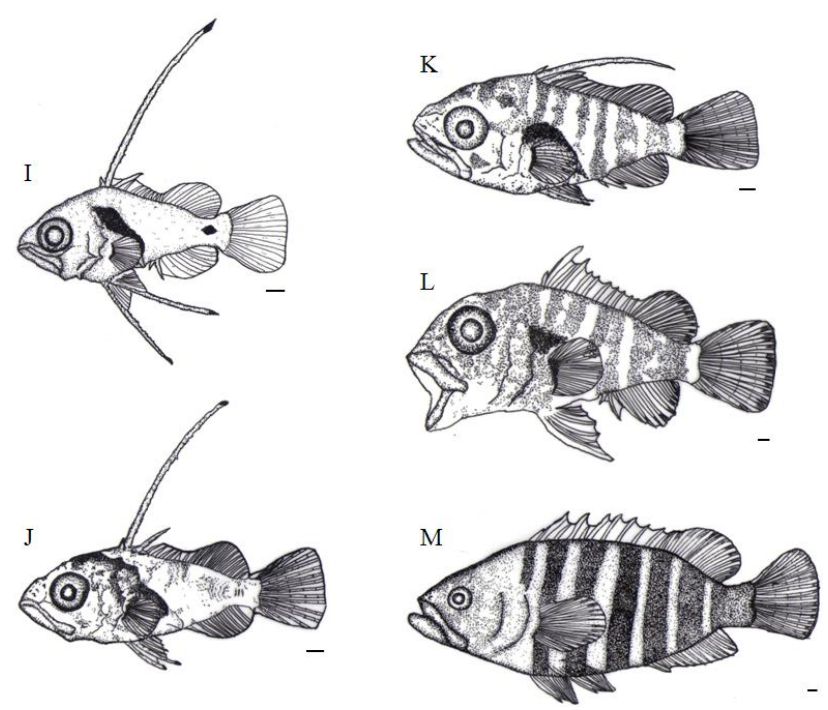

Fig. 5. Development of postlarvae and juvenile sevenband grouper, Epinephelus septemfasciatus. (I) $14.4 \mathrm{~mm}$ in TL postlarvae, 38 days after hatching; (J) $17.3 \mathrm{~mm}$ in $\mathrm{TL}$ postlarvae, 44 days after hatching; (K) $21.3 \mathrm{~mm}$ in TL juvenile, 52 days after hatching; (L) $32.9 \mathrm{~mm}$ in TL juvenile, 61 days after hatching; (M) $42.6 \mathrm{~mm}$ in TL juvenile, 71 days after hatching. Scale bars $=1.0 \mathrm{~mm}$.

an anal fin, as well as the caudal fin (Fig. 5L). After 71 days of hatching, the TL of juvenile was $40.5 \mathrm{~mm}$ to 45.4 $\mathrm{mm}(42.6 \pm 2.04 \mathrm{~mm})$. From the point where the back side of head starts through the fist bone of the dorsal fin, the first horizontal stripe was shown while the second horizontal stripe was clearly appeared in between third and fourth bone of the dorsal fin. The third stripe was located between fifth and sixth while the fourth horizontal stripe was shown between seventh and ninth. Similarly, fifth, sixth, and seventh stripes were clearly shown between tenth bone and second soft ray, third and tenth soft ray, and twelfth soft ray and the end of caudal peduncle, respectively. The length between the mouth and the front of anus, was approximately $55.1 \%$ of the TL, the anus, positioned around a bit behind of the centre of body in the larvae stage, was moved to the very centre of the body in the juvenile stage (Fig. 5M).

\section{Relative growth}

Throughout the breeding period of E. septemfasciatus larvae and juvenile, relative growth of the part length was shown in Fig. 6 and 7 respectively and calculated as follow.

$$
\begin{aligned}
& \mathrm{TL}=1.2820 \mathrm{BL}-0.4984 \mathrm{R}^{2}=0.9985 \\
& \mathrm{PL}=0.7046 \mathrm{BL}-0.6989 \mathrm{R}^{2}=0.9960 \\
& \mathrm{HL}=0.4160 \mathrm{BL}-0.3284 \mathrm{R}^{2}=0.9961 \\
& \mathrm{ED}=0.1441 \mathrm{BL}-0.0329 \mathrm{R}^{2}=0.9427 \\
& \mathrm{BD}=0.4666 \mathrm{BL}-0.6429 \mathrm{R}^{2}=0.9912 \\
& \mathrm{UJL}=0.1583 \mathrm{BL}+0.1880 \mathrm{R}^{2}=0.8702
\end{aligned}
$$

The TL respect to the BL was slowly growing from 1.90 $\mathrm{mm}$ to $6.56 \mathrm{~mm}$, subsequently it was growing fast in the juvenile stage when the TL was between $21.9 \mathrm{~mm}$ and $38.4 \mathrm{~mm}$, when all fins and muscles were developing. The preanal length respect to BL was growing slowly between $0.58 \mathrm{~mm}$ and $3.15 \mathrm{~mm}$ in the early larvae period when start to develop the intestinal tract. Afterward, once developed the intestinal tract, the anus, located in front part of the body moved to the very centre of the body and showed fast growth from $11.5 \mathrm{~mm}$ through $22.0 \mathrm{~mm}$.

The HL respect to $\mathrm{BL}$ was also growing slowly from $0.58 \mathrm{~mm}$ to $1.93 \mathrm{~mm}$ in the early larvae period while it grew fast in between $6.84 \mathrm{~mm}$ and $12.3 \mathrm{~mm}$. The ED, respect to the $\mathrm{BL}$ grew up slowly between $0.15 \mathrm{~mm}$ and $0.24 \mathrm{~mm}$; this was the period when melanophores were began to precipitate in eyes and all yolk was absorbed. In contrast, there was slow growth from $2.65 \mathrm{~mm}$ to $4.16 \mathrm{~mm}$ after melanophores were completely precipitated. The BD respect to BL was growing slowly in between $0.55 \mathrm{~mm}$ (right after the hatching) and $2.01 \mathrm{~mm}$ when yolk was absorbed in the postlarvae stage, it was growing fast between $6.62 \mathrm{~mm}$ to $14.7 \mathrm{~mm}$ when the metamorphosis was proceeding. The UJL respect to the $\mathrm{BL}$ was growing slowly in between $0.30 \mathrm{~mm}$ and $0.67 \mathrm{~mm}$ this might be because early larvae is not very active and the amount of food intake is not significant. After this, there was an 


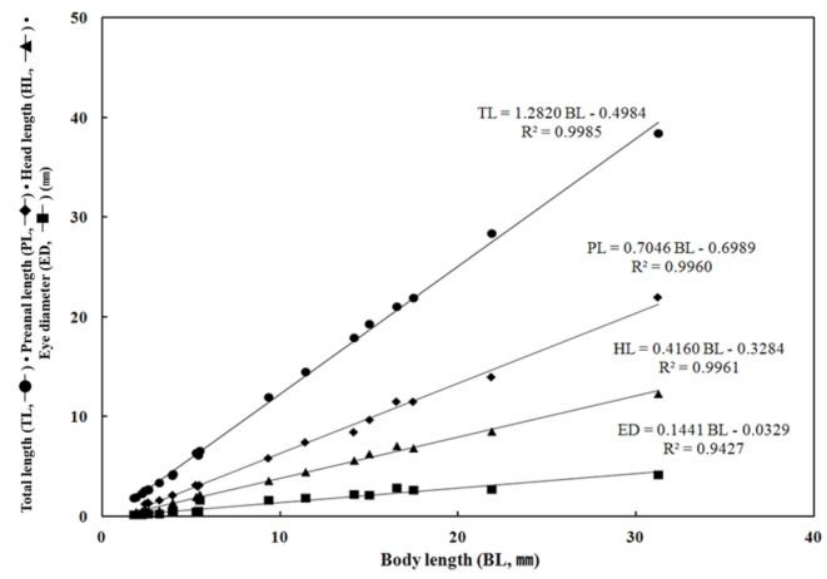

Fig. 6. Relative growth of total length, preanal length, head length and eye diameter against body length in larvae and juvenile sevenband grouper, Epinephelus septemfasciatus.

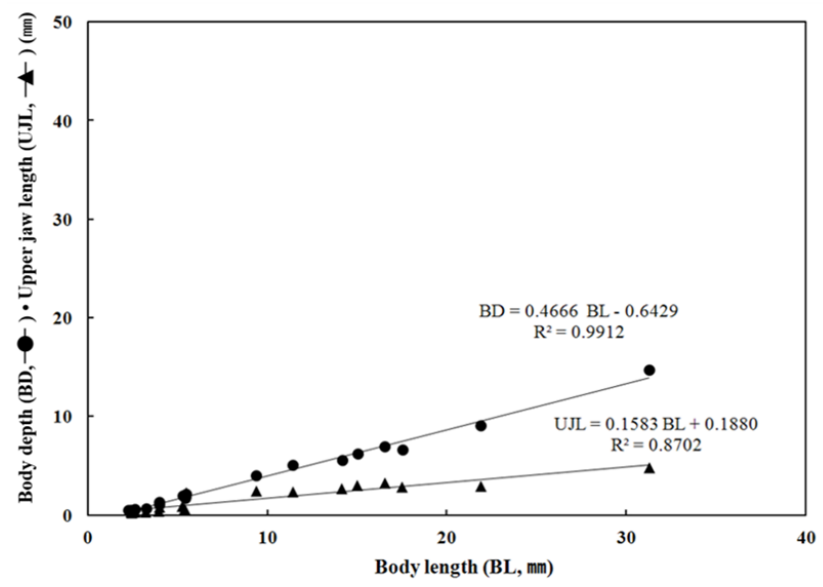

Fig. 7. Relative growth of body depth and upper jaw length in larvae and juvenile sevenband grouper, Epinephelus septemfasciatus.

increase in food intake between $2.83 \mathrm{~mm}$ and $4.81 \mathrm{~mm}$ and a fast growth as both lower and upper jaws were developing.

\section{DISCUSSION}

Fertile eggs of E. septemfasciatus arecolorless, transparent, and spherical, they are characterized by aseparated pelagic egg with single oil droplet (Liao \& Leano, 2008).

The average diameter of fertile eggs is about $0.85 \mathrm{~mm}$ in the study which is in good agreement with previous reports elsewhere Lee \& Go (2003) and Kitajima et al. (1991). Compared to other Serranidae, it was slightly bigger than those of E. akaara 0.71 0.82 $\mathrm{mm}$ (Song, 1998) and Humpback grouper, Cromileptes altivelis $0.83 \mathrm{~mm}$ (Bulanin et al., 2005) while relatively smaller than E. bruneus 0.90 mm (Lee \& Go, 2003) and Nassau grouper, E. striatus $0.92 \mathrm{~mm}$ (Allyn et al., 1992). It has been widely known that water temperature impactonnotonly the development of fish egg but the growth and survival rate of larvae and juvenile in the seed production processes.

Ingeneral, higher water temperature facilitates the development of eggs while low temperature delays it. Therefore, each fish represent their optimal range of water temperature given their specific life style, ecological characteristics for normal development (Hokanson et al., 1973; Gunnes, 1979; Herzig \& Winkler, 1986; Rana, 1990).

When it comes to time consuming for hatching, in case of E. septemfasciatus, it took 48 hours when the water temperature was around $21.5 \sim 23.5^{\circ} \mathrm{C}$ in the study. According to Lee \& Go (2003), it took 46 hours and 35 hours at $22.0^{\circ} \mathrm{C}$ and $25.0^{\circ} \mathrm{C}$ of water temperature, respectively. Further, Kitajima et al. (1991) have shown that it takes approximately 30 35 hours for E. septemfasciatus to hatch at $21.2 \sim 23.2^{\circ} \mathrm{C}$ of water temperature. For E. akaara, it took 25.5 hours at $25.0^{\circ} \mathrm{C}$ of water temperature (Song, 1998 ) while E. bruneus needs 32 hours at $25.0^{\circ} \mathrm{C}$ of water temperature to hatch (Lee \& Go, 2003). Humpback grouper required 20 hours and 10 minutes at $27.0 \sim 28.0^{\circ} \mathrm{C}$ of water temperature (Bulanin et al., 2005) while Nassua grouper needed 27 29 hours at $23.0 \sim 30.0^{\circ} \mathrm{C}$, respectively. Taken together, it seems generally true that most Serranidae fishes tend to require shorter time to hatch with higher water temperature, indicating close association between water temperature and time required for hatching eggs.

These results seem to be general in the development of eggs of many species such as Girella punctata and $G$. melanichthys (Oh et al., 2010), Paralichthys olivaceus 
(Kim et al., 2010), Gadus macrocephalus (Lee et al., 2007), Scomber japonicas (Hwang et al., 2008), Takifugu pardalis (Han \& Cho, 2007), and Microstomus achne (Byun et al., 2009). When compare the TL of larvae right after hatching, the average of TL of E. septemfasciatus was $1.74 \mathrm{~mm}$ which is very closed to other studies elsewhere Lee \& Go (2003) and Kitajima et al. (1991). This was slighter longer than the average TL of E. akaara $1.65 \mathrm{~mm}$ (Song, 1998) as well as E. fasciatus 1.30 1.40 mm (Kawabe et al., 2009) while shorter than those of Humpback grouper $1.86 \mathrm{~mm}$ (Bulanin et al., 2005), Nassau grouper 1.70 1.80 mm (Allyn et al., 1992) as well as E. bruneus $2.02 \mathrm{~mm}$.

Serranidae fishes have been known to go through the metamorphosis processes that represent significant transformation in the postlarvae stage. In the study, we considered to be started as the second spinous ray of the dorsal fin and the first spinous ray of the ventral fin got elongated. When it comes to the timing, E. septemfasciatus began metamorphosis after 8 days of hatching and the TL was between $2.48 \sim 2.59 \mathrm{~mm}$. In other studies, for example, Lee \& Go (2003) reported that it was started after 9 days of hatching and TL was around $2.94 \mathrm{~mm}$. Further, Kitajima et al. (1991) reported that it initiated its metamorphosis after 13 days of hatching and the average TL was $3.45 \mathrm{~mm}$. Such morphological changes are shown in Pleuronectiformes fishes such as P. olivaceus (Han \& Kim, 1997), Pleuronectes herzensteini (Han \& Kim, 1999), and Platichthys stellatus (Byun et al., 2007). These Pleuronectiformes fishes used to have their eyes separated in prelarvae stage but represent morphological changes there by moving one eye to the other side and directing their body toward bottom. E. septemfasciatus only represent their partial morphological changes in spinous ray of the dorsal and ventral fins (known as late onset metamorphosis), while Pleuronectiformes fishes generally go through the significant metamorphosis. Even though it is somewhat difficult to determine the exact

Table 2. Comparison characters of the eggs, larvae and juvenile in the Serranidae

\begin{tabular}{|c|c|c|c|c|c|c|}
\hline Species & $\begin{array}{l}\text { Egg size } \\
(\mathrm{mm})\end{array}$ & $\begin{array}{c}\text { Hour of hatched } \\
\text { (water temp.) }\end{array}$ & $\begin{array}{c}\text { Total length of } \\
\text { newly hatched } \\
\text { larvae }(\mathrm{mm})\end{array}$ & $\begin{array}{c}\text { Days of } \\
\text { metamorphosis } \\
\text { total length }(\mathrm{mm})\end{array}$ & $\begin{array}{l}\text { Juvenile } \\
\text { (mm) }\end{array}$ & References \\
\hline \multirow{3}{*}{$\begin{array}{c}\text { Epinephelus } \\
\text { septemfasciatus }\end{array}$} & 0.85 & $\begin{array}{c}48 \mathrm{~h} \\
\left(21 \sim 23^{\circ} \mathrm{C}\right)\end{array}$ & 1.74 & $\begin{array}{l}8 \text { days } \\
(2.54)\end{array}$ & $\begin{array}{c}61 \text { days } \\
(32.9)\end{array}$ & Present study \\
\hline & 0.82 & $\begin{array}{c}46 \mathrm{~h} / 35 \mathrm{~h} \\
\left(22^{\circ} \mathrm{C} / 25^{\circ} \mathrm{C}\right)\end{array}$ & 1.75 & $\begin{array}{l}9 \text { days } \\
(2.94)\end{array}$ & - & $\begin{array}{l}\text { Lee \& Go, } \\
2003\end{array}$ \\
\hline & 0.82 & $\begin{array}{c}30 \sim 35 \mathrm{~h} \\
\left(21.2 \sim 23.2^{\circ} \mathrm{C}\right)\end{array}$ & 1.85 & $\begin{array}{c}13 \text { days } \\
(3.45)\end{array}$ & $\begin{array}{c}60 \text { days } \\
(30.0)\end{array}$ & $\begin{array}{c}\text { Kitajima et al., } \\
1991\end{array}$ \\
\hline $\begin{array}{l}\text { Epinephelus } \\
\text { akaara }\end{array}$ & $0.71 \sim 0.82$ & $\begin{array}{c}25 \text { h } 30 \mathrm{~min} \\
\left(25^{\circ} \mathrm{C}\right)\end{array}$ & 1.65 & - & - & Song, 1988 \\
\hline $\begin{array}{l}\text { Epinephelus } \\
\text { striatus }\end{array}$ & 0.92 & $\begin{array}{c}27 \sim 29 \mathrm{~h} \\
\left(23 \sim 30^{\circ} \mathrm{C}\right)\end{array}$ & $1.70 \sim 1.80$ & - & $\begin{array}{c}40 \text { days } \\
(13.5)\end{array}$ & $\begin{array}{l}\text { Allyn et al., } \\
1992\end{array}$ \\
\hline $\begin{array}{l}\text { Epinephelus } \\
\text { bruneus }\end{array}$ & 0.90 & $\begin{array}{c}32 \mathrm{~h} \\
\left(25^{\circ} \mathrm{C}\right)\end{array}$ & 2.02 & - & $\begin{array}{c}50 \text { days } \\
(10.5)\end{array}$ & $\begin{array}{l}\text { Lee \& Go, } \\
2003\end{array}$ \\
\hline $\begin{array}{l}\text { Epinephelus } \\
\text { fasciatus }\end{array}$ & - & - & $1.30 \sim 1.40$ & - & $\begin{array}{c}30 \text { days } \\
(12.4)\end{array}$ & $\begin{array}{c}\text { Kawabe et al., } \\
2009\end{array}$ \\
\hline $\begin{array}{l}\text { Cromileptes } \\
\text { altivelis }\end{array}$ & 0.83 & $\begin{array}{l}20 \mathrm{~h} 10 \mathrm{~min} \\
\left(27 \sim 28^{\circ} \mathrm{C}\right)\end{array}$ & 1.86 & - & - & $\begin{array}{l}\text { Bulanin et al., } \\
2005\end{array}$ \\
\hline
\end{tabular}


size and timing of metamorphosis for larvae, there might be interspecies differences depending upon their growth, warranting further investigation regarding larvae breeding as well as their growth.

When comparing the days to migrate to the juvenile stage, E. septemfasciatus took about 61 days after hatching the average TL was $32.9 \mathrm{~mm}$. On the other hand, Kitajima et al. (1991) reported that it took about 60 days and their average TL was also similar average $30.0 \mathrm{~mm}$. In case of $E$. bruneus, it took about 50 days for an average and the TL was around $10.5 \mathrm{~mm}$ (Lee \& Go, 2003). According to Kawabe et al. (2009) it took 30 days for E. fasciatus to proceed the juvenile stage and their average BL was 12.4 mm (Kawabe et al., 2009) while Nassau grouper (Allyn et al., 1992) required 40 days for average and BL was 13.5 mm (Table 2).

Taken altogether, in the present study, we investigated the egg developmental processes in seed production through the investigation of the early life history of E. septemfasciatus and the required time as well as morphological development stages of larvae and juvenile throughout their growth. There are still many difficulties in regard to seed production of E. septemfasciatus and it is warranted to investigate further in particular about hormone induced spawning, production of improved quality of eggs, organized management of parent fishes, elucidation of maturation timing, and selection of hormone application.

\section{ACKNOWLEDGEMENT}

This research was supported by grants from the National Fisheries Research and Development Institute (NFRDI) in Korea (RP-2014-AQ019).

\section{REFERENCES}

Allyn B, Powell, John W, Tucker JR (1992) Egg and larval development of laboratory reared nassau grouper, Epinephelus striatus (Pisces, Serranidae). Bull Marine 50:171-185.

Bulanin U, Saad CR, Kamarudin MS, Affandi R, Sudaryono A (2005) Eggs and prelarvae development for humpback grouper, Cromileptes altivelis, (Valencee) larvae. Aqua Indonesia 6:115-121.

Byun SG, Lee SH, Hwang JH, Han KH, Yeon IH, Kim JD, Lee JH, Lee BI (2009) Effect of water temperature on the embryonic development of slime flounder Microstomus achne. Dev Reprd 13:265-270.

Gunnes K (1979) Survival and development of atlantic salmon eggs and fry at three different temperature. Aquaculture 16:211-218.

Han KH, Cho JK (2007) Effect of water temperature on the embryonic development of pather puffer, Takifugu pardalis. J Aquaculture Korean 20:265-269.

Herzig A, Winkler H (1986) The influence of temperature on the embryonic development of three cyprinid fishes, Abramis brama, Chalcalburnus chalcoides and Vimba vimba. J Fish Biol 28:171-181.

Hokanson KEF, McCormick JH, Jones BR (1973) Temperature requirements for embryos and larvae of the northern pike, Esox lucius (Linnaeus). Trans Am Fish Soc 102:89-100.

Hwang HK, Kim DH, Park MW, Yoon SJ, Lee YH (2008) Effects of water temperature and salinity on the egg and larval of chub mackerel Scomber japonicus. J Aquaculture Korean 21:234-238.

Kawabe K, Kohno H (2009) Morphological development of larval and juvenile blacktip grouper, Epinephelus fasciatus. Fish Sci 75:1239-1251.

Kim YS, Do YH, Kim SY, Chang YJ (2010) Developmental speed of olive flounder Paralichthys olivaceus eggs in various water temperature. Dev Reprod 14:59-63.

Kitajima C, Takaya M, Tsukashima Y, Arakawa T (1991) Development of eggs, larvae and juvenile of the grouper, 
Epinephelus septemfasciatus, reared in the laboratory. Japan J Ichthyol 38:47-55.

Lee JY, Lee CS, Kim WK, Park SU, Min BH (2007) Effects of water temperature on egg development, hatching and larval growth rearing of the pacific cod Gadus macrocephalus. J Aquaculture Korean 20:260264.

Lee YD, Go KM (2003) Aquatic industrialization by development of reproductive technology of sevenband grouper, Epinephelus septemfasciatus. Jeju Univ. pp.1-86.

Liao IC, Leano EM (2008) The aquaculture of grouper. Afs Was FSt Ntou. pp.49-60.

Miyailara J, Arakawa T, Takaya M (1989) Growth and morphology of young hybrids of Epinephelus akaara with E. septemfasciatus and E. akaara with E. moara. Bull NPIF 15:5-11.

Miyaki K, Yamada T, Nagano N, Takami I, Kadomura K, Donai H, Tsukiyama Y, Kubota Y (2006) Artificial insemination method of sevenband grouper Epinephelus septemfasciatus using cryopreserved sperm. Bull NPIF $32: 17-21$.

Nagano N, Hozawa A, Fujiki W, Yamada T, Miyaki K, Sakakura Y, Hagiwara A (2007) Skeleton development and deformities in cultured larval and juvenile sevenband grouper, Epinephelus septemfasciatus (Thunberg). Aqua Res 38:121-130.

Oh BS, Choi YU, Ku HD, Kim SC, Jung MM, Park HS (2010) The effect of water temperature on egg development stages of largescale blackfish Girella punctata and smallscale blackfish Girella melanichthys. Dev Reprod 14:51-58.

Rana KG (1990) Influence of incubation temperature on Oreo-chromis niloticus (L.) eggs and fry. I. Gross embryology, temperature tolerance and rates of embryonic development. Aquaculture 87:165-181.

Rusell FS (1976) The Eggs and Planktonic Stages of British Marine Fishes. Academic Press Inc. London. pp.524.
Song CB (1998) Study on seed production of the red grouper, Epinephelus akaara, and its feed organism. Jeju Univ. pp.23-97.

Tanaka Y, Sakakura Y, Chuda H, Hakiwara A, Yasumoto S (2005) Food selectivity of seven-band grouper Epinephelus septemfasciatus larvae fed different sizes of rotifers. Nippon Suisan Gakkaishi 71:911-916.

Kim BH, Kim KM, Lee YD, Song CB, Rho S (1997) Reproductive biology of the sevenband grouper, Epinephelus septemfasciatus I. The effect of HCG on ovulation induction. J Aquaculture Korean 10:55-61.

Kim IS, Choi Y, Lee CL, Lee YJ, Kim BJ, Kim JH (2005) Illustrated Book of Korean Fishes. Kyo Hak Publishing, Seoul, Korean. pp.276-286.

Kim CS, Kim WS, Nishizawa T, Oh MJ (2012) Prevalence of viral nervous necrosis (VNN) in sevenband grouper Epinephelus septemfasciatus farms. J Fish Pathol 25: 111-116.

Byun SG, Lee BI, Lee JH, Ku HD, Park SU, Yoon SM, Hwang SY, Kim YC, Han HG (2007) Egg development and morphological change of larvae and juvenile of the starry flounder, Platichthys stellatus. Korean J Ichthyol 19:350-359.

Sohn SG, Chun SK (1999) Pathogenicity of the fish nodavirus causing viral nervous necrosis of sevenband grouper, Epinephelus septemfasciatus. J Fish Pathol 12:107-113.

Sohn SG, Park MA, Lee SD, Chun SK (1991) Studies on the mass mortality of the ciltured grouper, Epinephelus septemfasciatus. J Fish Pathol 4:87-94.

Song HB, Choi SS (2000) Reproductive ecology and early life history of paradise fish, Macropodus chinensis (Pisces : Belontidae) in aquarium. Korean J Limnol $33: 282-294$.

Song YB, Baek HJ, Kim HB, Lee KJ, Kiyoshi S, Lee YD (2005) Induced sex reversal of sevenband grouper, Epinephelus septemfasciatus by $17 \alpha$-methyltestosterone. 
$\mathrm{J}$ of Aquaculture 18:167-172.

Yang YL (1987) Phototaxis of fish 6. Response of sea bass to the white lights. Bull Korean Fish Tech Soc 23:2733.

Yang YS, Seo DY, Lee CH (1999) A basic study for the behaviour control of sevenband grouper, Epinephelus septemfasciatus, to underwater low frequency sound I. The auditory thresholds of sevenband grouper. Bull Korean Soc Fish Tech 35:391-396.
Han KH, Kim YU (1997) The early life history of the flounder, Paralichthys olivaceus I. Development of egg, larvae and juveniles. Bull Yeosu Nat'l Fish Univ 11:105-117.

Han KH, Kim YU (1999) Eggs development and morphology of larvae of the flounder, Limanda herzensteini. Korean J Ichthyol 11:86-93.

Jung MK (1977) The Fishes of Korea. Illjisa. pp.307. 